Snežana Kirin ${ }^{1}$

Gordana Gavrić ${ }^{2}$

Sandra Kirin ${ }^{3}$
JEL: M14

DOI: $10.5937 /$ industrija48-29810

UDC: 005.73/.74:334.7(497.11)

Original Scientific Paper

\title{
Organizational culture in Serbia in relation to the characteristics of organization - empirical reserch
}

\author{
Article history: \\ Received: 9 November 2020 \\ Sent for revision: 17 December 2020 \\ Received in revised form: 20 December 2020 \\ Accepted: 22 December 2020 \\ Available online: 31 December 2020
}

Abstract: In moder business conditions, organizational culture is recognized as a powerful tool for long-term survival and development of the organization. The purpose of this paper was to research whether and in what way the characteristics of organizations - such as its size, ownership structure, activity, domestic or foreign - influence the organizational culture. Because of continuous and rapid changes and enormous competition, which are features of modern business, the Denison model of organizational culture was chosen because it emphasizes the need for balance between requirements for organizational stability (factors of mission and consistency) and requirements for its adaptability (factors of involvement and adaptability). The survey covered a sample of 1,000 employees and the data was statistically processed using the one-way ANOVA method. The obtained results show the influence of organizational characteristics on its ability to balance the internal and external focus of the organization, its stability, and its ability to change. Likewise, there should be a certain organizational cultural transformation as a response to the paradigm change in wider environment should be a certain organizational

\footnotetext{
${ }^{1}$ University of Belgrade, Innovative Center of Faculty of Mechanical Engineering

${ }^{2}$ Faculty of Business Economics and Entrepreneurship, gordana.gavric@vspep.edu.rs

${ }^{3}$ Ernst\&Young d.o.o.
}

Industrija, Vol.48, No.4, 2020 
cultural transformation as a response to the paradigm change in wider environment.

Keywords: organizational culture, stability, flexibility, internal focus, external focus

\section{Organizaciona kultura u Srbiji u odnosu na karakteristike organizacije- empirijsko istraživanje}

Apstrakt: $U$ savremenim uslovima poslovanja organizaciona kultura prepoznata je kao moćno sredstvo za dugoročni opstanak i razvoj organizacije. Svrha ovog rada bila je istražiti da li i na koji način karakteristike organizacija poput veličine, vlasničke strukture, delatnosti, činjenice da li je vlasništvo domaće ili strano - utiču na organizacionu kulturu. Zbog kontinuiranih i brzih promena i ogromne konkurencije kao odlike savremenog poslovanja, izabran je Denisonov model organizacione kulture jer naglašava potrebu za ravnotežom između zahteva za organizacionom stabilnošću (faktori misije $i$ doslednosti) i zahteva za njenom adaptabilnošću (faktori uključenosti $i$ prilagodljivosti). Istraživanje je obuhvatilo uzorak od 1.000 zaposlenih, a podaci su statistički obrađeni metodom one-way ANOVA. Dobijeni rezultati pokazuju uticaj organizacionih karakteristika na njenu sposobnost uravnoteženja unutrašnjeg i spoljašnjeg fokusa organizacije, stabilnost i sposobnost promene. Takođe, uočena je potreba za nekom vrstom organizacione kulturne transformacije kao odgovora na promenu paradigme u širem okruženju.

Ključne reči: organizaciona kultura, stabilnost, fleksibilnost, unutrašnji fokus, spoljni fokus

\section{Introduction}

The view "that the key to long-term success does not lie in individual strategies or in effective resource management, but in the so far neglected management dimension, the cultural dimension" (Cardona \& Rey, 2008), is widely accepted in modern management. "Charles A. O'Reilly III, a professor of management at the Stanford Graduate School of Business, points to a Stanford study from 2014 that he says demonstrates a clear relationship between organizational culture and a broad set of business outcomes, including company reputation, analysts' stock recommendations, employee attitudes and financial performance" (Gurchiek, 2015). Yazdi, Ali Jabaroti, Hoseyn Eslami state that culture, as a set of common beliefs and values influencing the behavior and the thoughts of the staff, may be a resource of dynamics and motion, or it can put an obstacle in the way of organizational progress (Yazdi, \& Eslami, 2015). "Organizational 
culture is the key to organizational excellence, and the function of leadership is the creation and management of culture (Schein, 1992)" (Khosla, 2015). Simply, "culture has been important, because acting without knowing cultural forces (which have been involved) might have unpredicted and unwanted outcomes" (Ahmady, Nikooravesh, \& Mehrpour,2016).

Because of its proven effect on business, organizational culture has become significantly represented in the hierarchical structure of the economic entity's organizational problems. It gained importance especially with the beginning of the economical crisis, and it is believed that this interest will grow in the future.

The model of organizational culture is considered a set of basic assumptions, values and norms that an employee has developed by learning how to solve problems of external adaptation and internal integration. It is an important organizational value and it should be transferred to the new members of the organization as the correct way of thinking in relation to organizational problems.

In order to succeed in the long run, a modern organization has to be proactive, has to change and to adapt quickly to what the future holds, which makes flexibility the most desirable global trait of today. Modern successful organizations use more flexible forms of organizational structures, which brings them ability "to keep more active control of their future, rather than to wait and react to changes in their market" (Ackoff, Magidson, \& Addison, 2006). However, we cannot ignore the fact that it is equally important for an organization to develop elements that allow stability. "Stable organizations with a high degree of unity are more likely to survive in times of crisis" (Gavric \& Stankovic, 2015). Realizing flexibility while maintaining stability is the organizational culture formula, which is believed to bring sustainable development.

Because of these desirable characteristics of modern organizations, we chose the Denison organizational culture model, based on four traits of organizational culture: "involvement, consistency, adaptability and mission" (Denison \& Mishra, 1995). Mission and consistency in work contribute to stability, while involvement and adaptability bring desired flexibility to organizations. Numerous studies have tested Denison organizational culture model in a specific pattern. Thus, for example, Kokina and Ostrovska, in their "research on a sample of 63 employees, working in the $X$ region Council, involved in the survey, find that all factors, which Denison offers as external and internal factors affecting organizational culture, are important for the work of region municipality and essentially affect its efficiency" (Kokina \& Ostrovska, 2013). According to Zeng, Jin, Guo and Zhang, who used the Denison model in the research about Chinese enterprise project culture, aforementioned model can be helpful in 
finding the "advantages and disadvantages of project culture construction through measurements, and thus providing suggestions for the project team to improve project performance" (Yucheng, Maozhu \& Zhiwei, 2015). Authors Ahmady, Nikooravesh and Mehrpour, in their paper Effect of Organizational Culture on Knowledge Management Based on the Denison Model (2016), point out that, in comparison with other organizational culture models, "the organizational culture model of Denison had following advantages:

- It evaluates group behaviour instead of personality;

- It performes measurements at the lowest organizational levels;

- It can be used at all organizational levels".

\section{Factors of Organizational Culture According to the Denison Model}

The essence of the Denison model consists of four dimensions:

- Mission: defining goals and strategies, monitoring their realization;

- Consistency: the existence of "strong" organizational culture and approach to business predictability;

- Involvement: common decision-making at the level where the best information is available;

- $\quad$ Adaptability: improving working mode and focus on consumers.

In Figure 1, Denison and Mishra (Denison \& Mishra, 1995) organized these four traits into a framework designed to "acknowledge two contrasts: the contrast between internal integration and external adaptation, and the contrast between change and stability. For example, involvement and consistency as their focus have the dynamics of internal integration, while mission and adaptability address the dynamics of external adaptation. This focus is consistent with Schein's (Schein, 1990) observation that culture, developed as an organization, learns to cope with the dual problems of external adaptation and internal integration. In addition, involvement and adaptability describe traits related to an organization's capacity to change, while consistency and mission are more likely to contribute to the organization's capacity to remain stable and predictable over time".

The mission differentiates a company in relation to its competitors, fuelling a system of values and beliefs that brings business success and competitive advantage to an organization (Kirin et II, 2019). According to the Denison model, mission means defining a meaningful long-term direction for an organization. "The indices of the Mission trait are: strategic direction and intent, goals and objectives and vision" (Denison \& Neale, 1999). "Developing 26

Industrija, Vol.48, No.4, 2020 
consistency amongst employees in achieving the mission and a clear definition of values and the business system, have become the most important tasks delegated to the modern managers who responsibly think of the future of their organizations" (Gavric at all, 2019).

Figure 1. Theoretical Model of Culture Traits

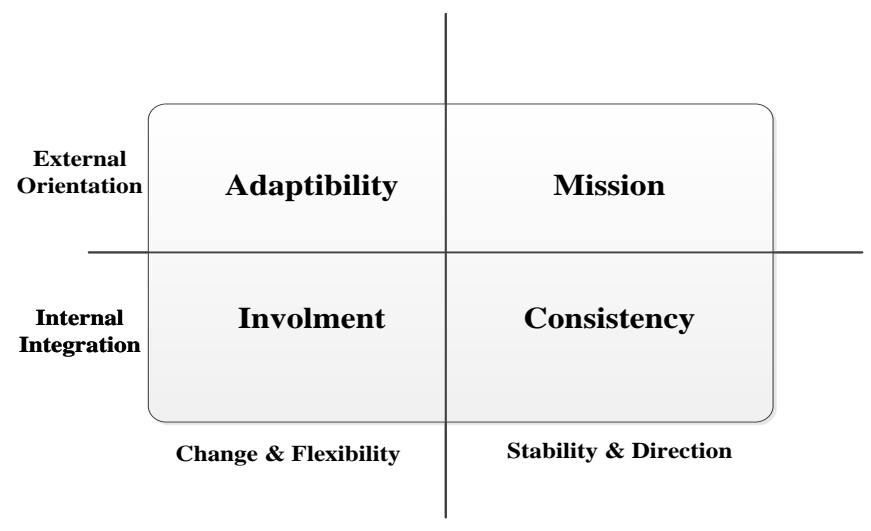

Source: Authors

The second factor important for stability of an organization, is consistency in work. According to the Denison model, consistency means defining values and systems that are the basis of a strong culture. The indices of "consistency trait are: coordination and integration, agreement and core values" (Denison \& Neale,1999). "By using established business practices, a company develops efficient processes and routines that support its long-term goals and strategies through knowledge which remains in the organization, regardless of the individual's departure" (Gavric \& Stankovic, 2015). Also, sharing core values and expectations between employees will make it easier to resolve disagreements and other problems in the functioning of the organization. Since conflict can prevent you from giving your best, work in accordance with your values can be a strong source of strength and motivation (Arnold, 2015).

Aspects of employee involvement, in accordance with the Denison model, have been seen through empowerment, personal development and team orientation. Yazdi and Eslami state that even "Ouch (1981) by his Z theory, recognized the employee involvement as the key factor to increased productivity. The concept of productivity through employees has been backed by 1300 major research in the United States of America. The results of these research have brought about such a scientific revolution in the American organizational culture that the 
organizations now tend to be more collaborative and staff's requirements and needs have become their primary goal" (Yazdi \& Eslami, 2015). "Effective organizations empower their people, build organizations as teams and develop human resources at all levels" (Denison et all., 2004). "By converting employees in a team the power of organization as a whole strengthens, simultaneously securing its competitiveness" (Gavric et all., 2017). The goal of education is to help develop talents of the individual, their knowledge, abilities and skills needed for performing a particular taks that best suits them in the established distribution of jobs (Garabinovic, 2015). Empowerment of employees, regardless of how it is implemented, "has lots of advantages for the organization; advantages such as job performance improvement, reducing mistakes and increasing the speed of decision-making and improving collaboration and innovation, and all of these lead to job performance improvement" (Roozitalab \& Majidi, 2017).

Adaptive companies are considered to be those that continuously monitor their environment (customers and competitors), respond quickly to current trends and requirements, and anticipate future developments on the market, which enables them to be successful and to have a more active control over the future. According to the Denison model, adaptability means transforming the demands of the business environment into action. "The indices of the adaptability trait are: creating change, customer focus, and organizational learning" (Denison \& Neale, 1999). Similarly, Manuel Ramón and Tejeiro Koller explain "organizational adaptive capability as a dynamic process of continuous learning, which permits an increase in firm innovation, leading to the potential for the company to create the change through innovation" (Ramon \& Koller, 2018). Simply put, "failures in organisational learning limit organisational adoption and ability to change" (Jovanovic, 2015).

\section{Research}

\subsection{Methodological Hypothetical Framework}

In order to present the position of organizational culture in Serbia, we have conducted a research by using the Denison questionnaire (Denison \& Neale, 1999). The questionnaire was constructed using the Likert type scale for measuring the level of agreement to statements $(1$ - completely disagree, 2 partly disagree, 3 - neither agree nor disagree, 4 - partly agree, 5 - completely agree). The survey was distributed personally to respondents, as well as via social network Facebook, and data were collected by written interviewing throughout 2015.

The data were analysed and interpreted using programs IBM SPSS Statistics 21. The analysis was conducted using descriptive statistical methods, and for 28

Industrija, Vol.48, No.4, 2020 
analysing relationships between characteristics of companies (their size, activity type and ownership structure, as well as domestic or foreign type of ownership) and age of employees and the organizational culture, we used the method for comparing means of subgroups, the one-way ANOVA.

The survey started from the basic research hypothesis:

1. The dimensions of the organizational culture according to the Denison model are influenced by the company's characteristics.

Derived hypotheses:

2. The size of the company affects the dimensions of the organizational culture.

3. The ownership structure influences the dimensions of the organizational culture.

4. The company's activities influence the dimensions of the organizational culture.

5. There are differences in the organizational culture of enterprises in Serbia in relation to the ownership factor, in terms of whether they are domestic or foreign-owned.

\subsection{Research Sample and Descriptive Result of Organizational Culture Dimensions}

The study included 1000 respondents from 29 different cities in Serbia and the sample description is given in Tables 1 and 2.

Table 1. Description of the personal characteristics of respondents

\begin{tabular}{|c|c|c|c|}
\hline $\begin{array}{c}\text { Personal } \\
\text { characteristics }\end{array}$ & $\begin{array}{c}\text { Categorization of } \\
\text { characteristics }\end{array}$ & Frequency & Percentage \\
\hline \multirow{3}{*}{ Gender } & Male & 520 & 52 \\
\cline { 2 - 4 } & Female & 460 & 46 \\
\cline { 2 - 4 } & Missing & 20 & 2 \\
\hline \multirow{4}{*}{ Age } & $18-30$ & 340 & 34 \\
\cline { 2 - 4 } & $31-40$ & 380 & 38 \\
\cline { 2 - 4 } & $41-50$ & 190 & 19 \\
\cline { 2 - 4 } & $41-60$ & 80 & 8 \\
\hline \multirow{3}{*}{ Work position } & Over 60 & 10 & 1 \\
\cline { 2 - 4 } & Worker & 640 & 64 \\
\cline { 2 - 4 } & Low-level manager & 190 & 19 \\
\cline { 2 - 4 } & Middle-level manager & 90 & 9 \\
\cline { 2 - 4 } & Top-level manager & 80 & 8 \\
\hline
\end{tabular}

Source: Authors' calculations 
Table 2. Description of companies

\begin{tabular}{|c|c|c|c|}
\hline & Characteristics of companies & Frequency & Percentage \\
\hline \multirow{4}{*}{$\begin{array}{l}\text { Company } \\
\text { size }\end{array}$} & 1-9 employees & 200 & 20 \\
\hline & 10-49 employees & 171 & 17.1 \\
\hline & 50-249 employees & 338 & 33.8 \\
\hline & 250 and more employees & 291 & 29.1 \\
\hline \multirow{13}{*}{$\begin{array}{l}\text { Company } \\
\text { activity }\end{array}$} & Services & 204 & 20.4 \\
\hline & $\begin{array}{l}\text { Public administration and mandatory social } \\
\text { security }\end{array}$ & 178 & 17.8 \\
\hline & Production & 140 & 14 \\
\hline & Education & 116 & 11.6 \\
\hline & Finance and insurance & 84 & 8.4 \\
\hline & Transportation and storage & 66 & 6.6 \\
\hline & Lodging and meals & 47 & 4.7 \\
\hline & Health and social care & 43 & 4.3 \\
\hline & Information and communication & 39 & 3.9 \\
\hline & Administrative and support service activities & 36 & 3.6 \\
\hline & Professional, scientific and technical activities & 26 & 2.6 \\
\hline & Arts, entertainment and recreation & 19 & 1.9 \\
\hline & Real estate services & 2 & 0.2 \\
\hline \multirow{2}{*}{$\begin{array}{l}\text { Company } \\
\text { ownership }\end{array}$} & Domestic & 860 & 86 \\
\hline & Foreign & 140 & 14 \\
\hline \multirow{3}{*}{$\begin{array}{l}\text { Ownership } \\
\text { structure }\end{array}$} & Private & 520 & 52 \\
\hline & State-owned & 440 & 44 \\
\hline & Public & 40 & 4 \\
\hline
\end{tabular}

Source: Authors' calculations

\subsection{The influence of company size on the dimensions of organizational} culture

In order to examine the impact of company size on the dimensions of organizational culture, the statistical method of one-way ANOVA was applied to all four dimensions of organizational culture: mission, consistency, involvement, and adaptability.

It was obtained that there are statistically significant differences for all four dimensions of organizational culture, in all subgroups, based on the criteria of the company size. Table 3 and Figure 2 present the mean values for all observed subgroups according to the company size. 
Table 3. Mean values for the dimensions of organizational culture, depending on the size of the company

\begin{tabular}{|l|c|c|c|c|c|}
\hline $\begin{array}{l}\text { Number of } \\
\text { employees }\end{array}$ & Count & Mission & Consistency & $\begin{array}{c}\text { Involvement of } \\
\text { employees }\end{array}$ & Adaptability \\
\hline $1-9$ & 200 & 3,84 & 3,77 & 3,80 & 3,85 \\
\hline $10-49$ & 171 & 3,64 & 3,66 & 3,45 & 3,73 \\
\hline $50-249$ & 338 & 3,50 & 3,41 & 3,21 & 3,33 \\
\hline 250 i vise & 291 & 3,48 & 3,29 & 3,10 & 3,33 \\
\hline
\end{tabular}

Source: Authors' calculations

The involvement of employees' dimension is most influenced by the increase in the number of employees and the sense of involvement in the life of the company drops significantly when the number of employees increases, Figure II.

The adaptability capability also deteriorates as the number of employees increases, but it is interesting that this decline is significant in the range from small to medium companies (Small and Medium Enterprise), and then it remains at the same level as the company grows, Figure 2 .

The values obtained for consistency are steadily decreasing with the increase in the number of employees, and the values obtained for mission are declining all the way the to companies of 49-250 employees, and then this value remains almost stable.

Figure 2. Influence of company size on dimensions of organizational culture

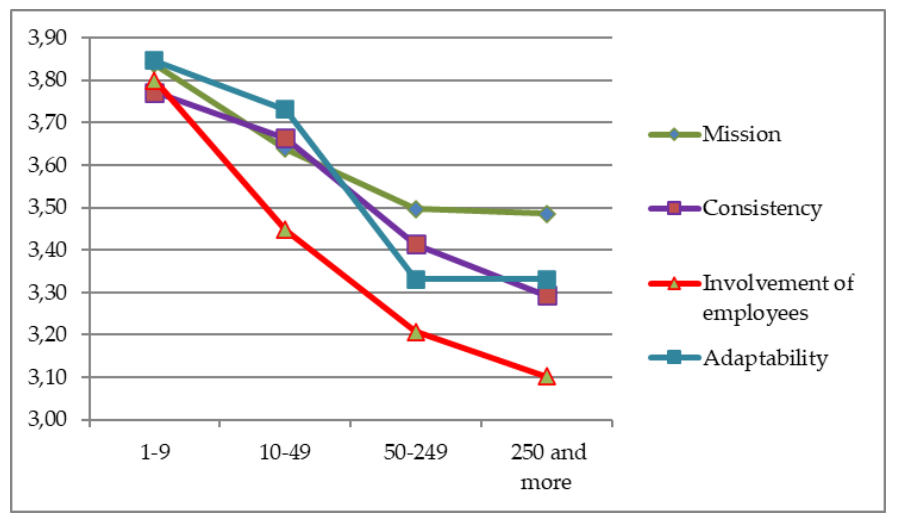

Source: Authors' calculations

Industrija, Vol.48, No.4, 2020 
Stability \& direction of the company are defined by its mission and consistency, and the change and flexibility capability is observed through the adaptability and involvement of employees dimensions. Obtained values of compliance between stability \& direction and capability for change and flexibility declined with the increase in the size of the company, Figure 3.

The results show that the relationship between flexibility and stability is such that the balance exists for companies up to 9 employees. With an increase in the number of employees, the balance is being broken and the smallest for companies of 250 or more employees in favor of stability (stable performance over time).

External orientation (focus on growth) of the companies, as well as internal focus, were analyzed through the dimensions of consistency and involvement of employees (related to operational performance, quality and employee satisfaction). The values obtained for external orientation and internal focus decreased with increasing the number of employees.

It can be seen that there is a balance of striving towards growth and keeping in mind quality, operational performance and employee satisfaction for companies with a small number of employees (up to 9).

Figure 3. The size of the company and the dimensions of the organizational culture

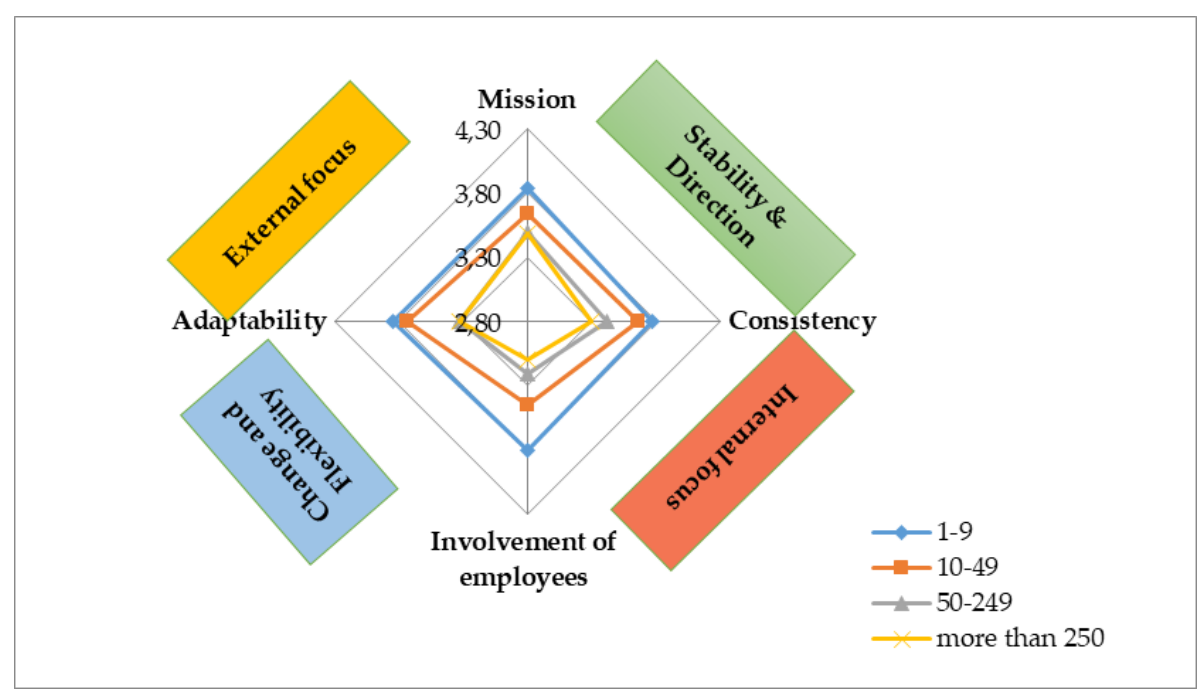

Source: Authors' calculations 
With the growing size of a company, the external focus becomes slightly higher than the focus on internal integration and employee satisfaction.

The results show that the relationship between flexibility (innovation and customer satisfaction) and stability \& direction is such that the balance exists for companies up to 9 employees. With an increase in the number of employees, the balance is breaking down in favor of having stability. The lowest value for all dimensions was obtained from companies of 250 or more employees, as shown on Figures 2 and 3.

The obtained results confirm the first derived hypothesis, that "the size of the company affects the dimensions of the organizational culture".

\subsection{The influence of the ownership structure of the company on the dimensions of the organizational culture}

In order to determine whether the company's ownership influences the dimensions of the organizational culture, we have observed 3 types of ownership: private, state, and public.

By comparing the mean values of all four dimensions - mission, consistency, involvement of employees and adaptability - relative to the ownership of companies (ANOVA Test), we got a statistically significant difference between all subgroups based on the criteria of ownership structure.

Table 4 and Figure 4 show the mean values of attitudes in all four dimensions of the organizational culture for subgroups, created according to ownership structure.

Table 4. Mean values for the dimensions of organizational culture, depending on the ownership structure

\begin{tabular}{|l|c|c|c|c|c|}
\hline $\begin{array}{c}\text { Ownership } \\
\text { structure }\end{array}$ & $\begin{array}{c}\text { Number of } \\
\text { respondents }\end{array}$ & Mission & Consistency & $\begin{array}{c}\text { Involvement of } \\
\text { employees }\end{array}$ & Adaptability \\
\hline $\begin{array}{l}\text { Private } \\
\text { company }\end{array}$ & 521 & 3,74 & 3,72 & 3,58 & 3,76 \\
\hline Public & 44 & 3,39 & 3,03 & 2,91 & 3,13 \\
\hline $\begin{array}{l}\text { State- } \\
\text { owned } \\
\text { company }\end{array}$ & 435 & 3,37 & 3,26 & 3,08 & 3,24 \\
\hline
\end{tabular}

Source: Authors' calculations

The results show that the highest results, i.e. the best levels of organizational culture, were obtained in private companies with a very high indicator. For them, mission and adaptability are 3.74 and 3.76 respectively, as well as internal integration indicators, consistency and adaptability, which are lower, but still the 
highest in relation to other types of ownership structure $(3.72,3.58)$. Adaptability and involvement indicators are also the highest among private companies, although the obtained value is lower than the stability \& direction value, Table 4 and Figure 4.

State-owned companies have the lowest values for all dimensions of organizational culture: 3.37 for mission, 3.26 for consistency, 3.08 for employee involvement and 3.24 for adaptability.

Figure 4. Influence of ownership structure of the company on the dimensions of organizational culture

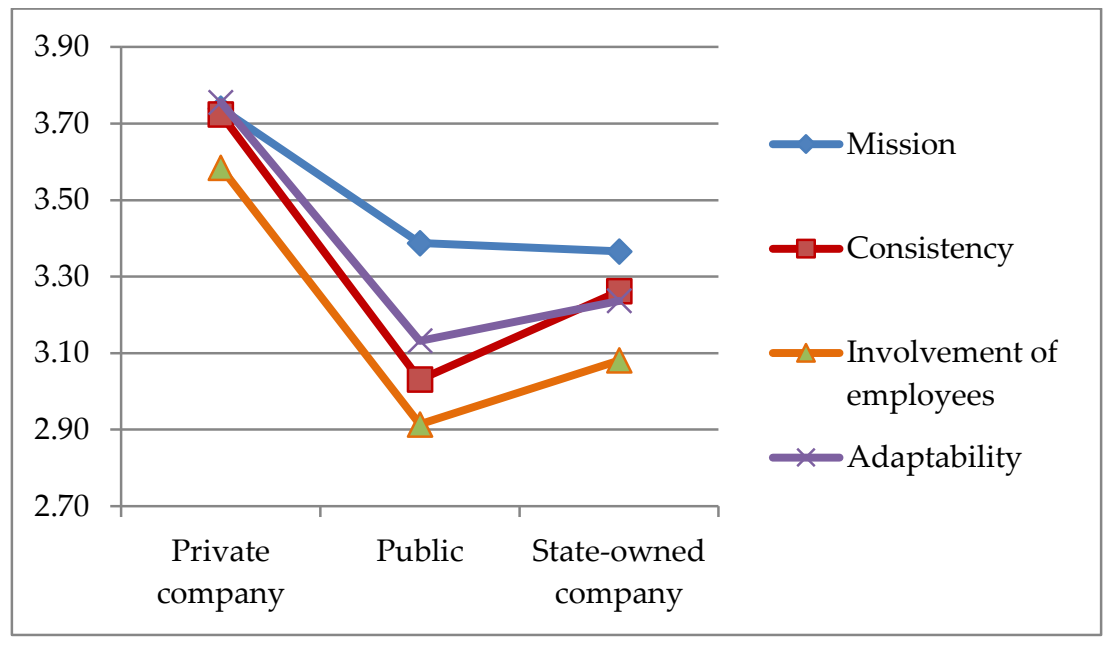

Source: Authors' calculations

Public companies have lower values of the organizational culture dimensions, except for the mission values. Employees of these companies gave a very low value for their involvement (2.91). Consistency is also low, 3.08, while adaptability value is 3.13 , Table 4 and Figure 4.

Accordingly, the lower values of all indicators (external orientation, internal integration, stability and flexibility) were obtained for state-owned companies, Figure 5.

Private companies also best balance the stability value of the company and its flexibility, as the two necessary, but opposing demands. The balance between stability and flexibility, as well as between internal integration and external orientation in state and public companies, has been significantly impaired by the low involvement of employees. The obtained results confirm the second 
derived hypothesis that "the ownership structure influences the organizational culture dimensions."

Figure 5. Ownership structure of the company and dimensions of organizational culture

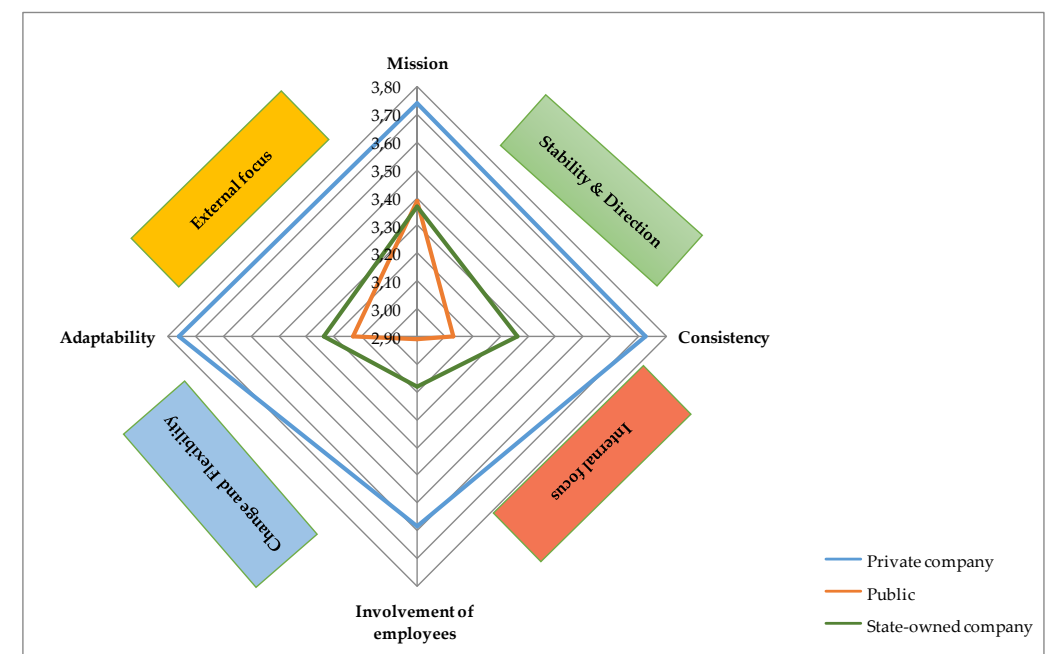

Source: Authors' calculations

3.5. The influence of the activity of the company on the organizational culture dimensions

The classification of activities, listed in Table II, is regulated by the Decree of the Government of the Republic of Serbia on Classification of Activities for 2010. There were only 2 employees from the Real estate services, and they were not taken into account.

By applying the ANOVA test in the examination of the mission, consistency, adaptability and involvement of employees, a statistically significant difference between all subgroups performing different economic activities was obtained.

Table 5 and Figure 6 present the influence of the company's activity on the dimensions of the organizational culture. 
Table 5. Mean values for the dimensions of organizational culture, depending on the activities of the company

\begin{tabular}{|l|c|c|c|c|c|}
\hline \multicolumn{1}{|c|}{ Activity } & $\begin{array}{c}\text { Number of } \\
\text { respondents }\end{array}$ & Mission & Consistency & $\begin{array}{c}\text { Involvement } \\
\text { of } \\
\text { employees }\end{array}$ & Adaptability \\
\hline $\begin{array}{l}\text { Public } \\
\text { administration and } \\
\text { mandatory social } \\
\text { security }\end{array}$ & 178 & 3,39 & 3,26 & 3,09 & 3,22 \\
\hline Production & 140 & 3,58 & 3,50 & 3,35 & 3,54 \\
\hline Education & 116 & 3,88 & 3,85 & 3,65 & 3,86 \\
\hline $\begin{array}{l}\text { Finance and } \\
\text { insurance }\end{array}$ & 84 & 3,43 & 3,32 & 3,21 & 3,39 \\
\hline $\begin{array}{l}\text { Transportation and } \\
\text { storage }\end{array}$ & 66 & 3,31 & 3,09 & 2,98 & 3,17 \\
\hline Lodging and meals & 47 & 3,54 & 3,64 & 3,43 & 3,68 \\
\hline $\begin{array}{l}\text { Health and social } \\
\text { care }\end{array}$ & 43 & 3,54 & 3,43 & 3,22 & 3,42 \\
\hline $\begin{array}{l}\text { Information and } \\
\text { communication }\end{array}$ & 39 & 3,48 & 3,57 & 3,58 & 3,46 \\
\hline $\begin{array}{l}\text { Administrative and } \\
\text { support service } \\
\text { activities }\end{array}$ & 36 & 3,66 & 3,72 & 3,65 & 3,79 \\
\hline $\begin{array}{l}\text { Professional, } \\
\text { scientific and } \\
\text { technical activities }\end{array}$ & 26 & 3,82 & 3,94 & 3,76 & 3,60 \\
\hline $\begin{array}{l}\text { Arts, entertainment } \\
\text { and recreation }\end{array}$ & 19 & 3,56 & 3,28 & 3,30 & 3,48 \\
\hline Services & 204 & 3,62 & 3,57 & 3,76 & 3,59 \\
\hline
\end{tabular}

Source: Authors' calculations

Figure 6 shows the values of the organizational culture dimensions for the following economic activities: production, education, health and social care, services, information and communication and professional, scientific and technical activities. Figure 7 shows the dimensions of the Denison model for the activities production, education, transportation and storage; health and social care; information and communication; public administration; and mandatory social security and services.

The obtained results show that the highest values for the organizational culture dimensions are achieved in companies whose activities are education and professional, scientific and technical. The lowest values for the organizational culture dimensions were obtained in the companies whose activity is transportation and storage, Table 5 and Figure 6 . The lowest values are generally obtained for the dimension of employee involvement, and are particularly low in public administration and mandatory social security, finance 
and insurance and health and social care, which is an unexpected result and indicates to a potential issue.

Figure VI: Influence of activity of the company on the organizational culture dimensions

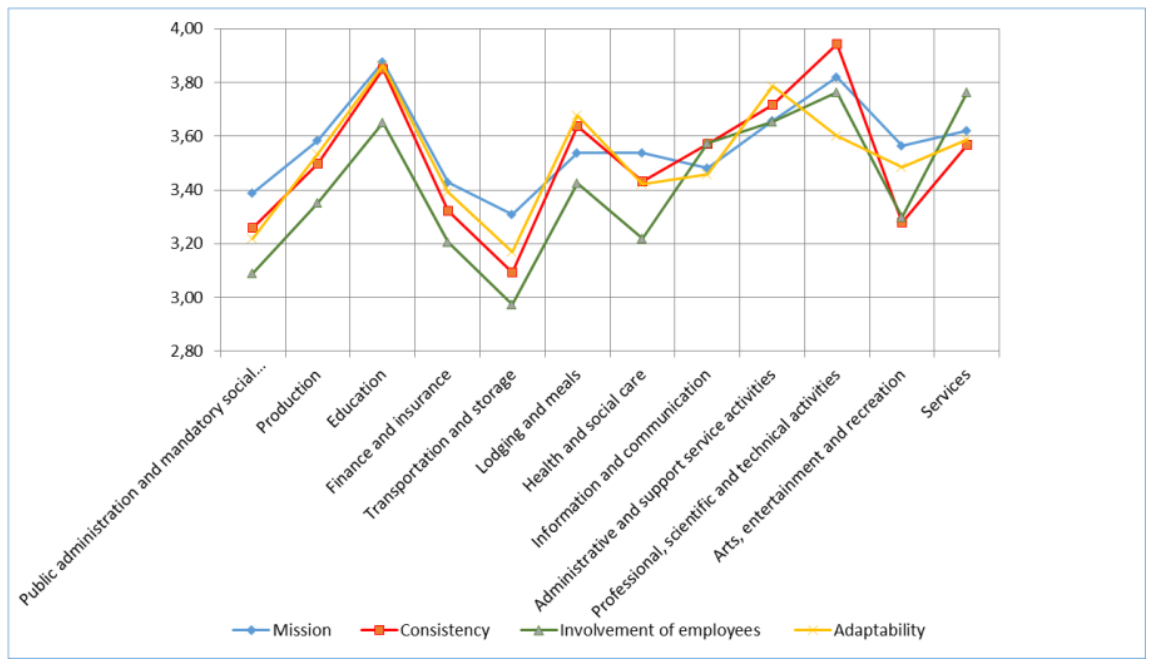

Source: Authors' calculations

When considering all four dimensions of the organizational culture, according to the Denison model, the lowest values were obtained for involvement of employees for activities: Public administration and mandatory social security; Production; Education; Finance and insurance; Transportation and storage; Lodging and meals; Health and social care. This means that the lowest values in these activities were obtained for indicators of Internal Integration in relation to the External Orientation. This also shows that higher values were obtained for stability \& direction than for change \& flexibility, and there is an imbalance.

Figure 7 shows that values for the external focus indicator are bigger than the value of internal integration for health and social care, public administration and mandatory social security, transport and storage activities: They also have higher values for stability \& direction indicators than for change \& flexibility.

In activities related to information and communication, the obtained results show that the indicators of internal integration are a bit higher than the external orientation indicators. When it comes to professional, scientific and technical activities, indicators obtained for stability \& direction are higher than the indicator for change \& flexibility. The results closest to the balance of external 
orientation and internal integration, as well as the stability and flexibility of the companies were obtained in the services, information and communication. The obtained results confirm the third derived hypothesis that the "company's activity influences the organizational culture".

Figure 7. Activity of the company and dimensions of organizational culture

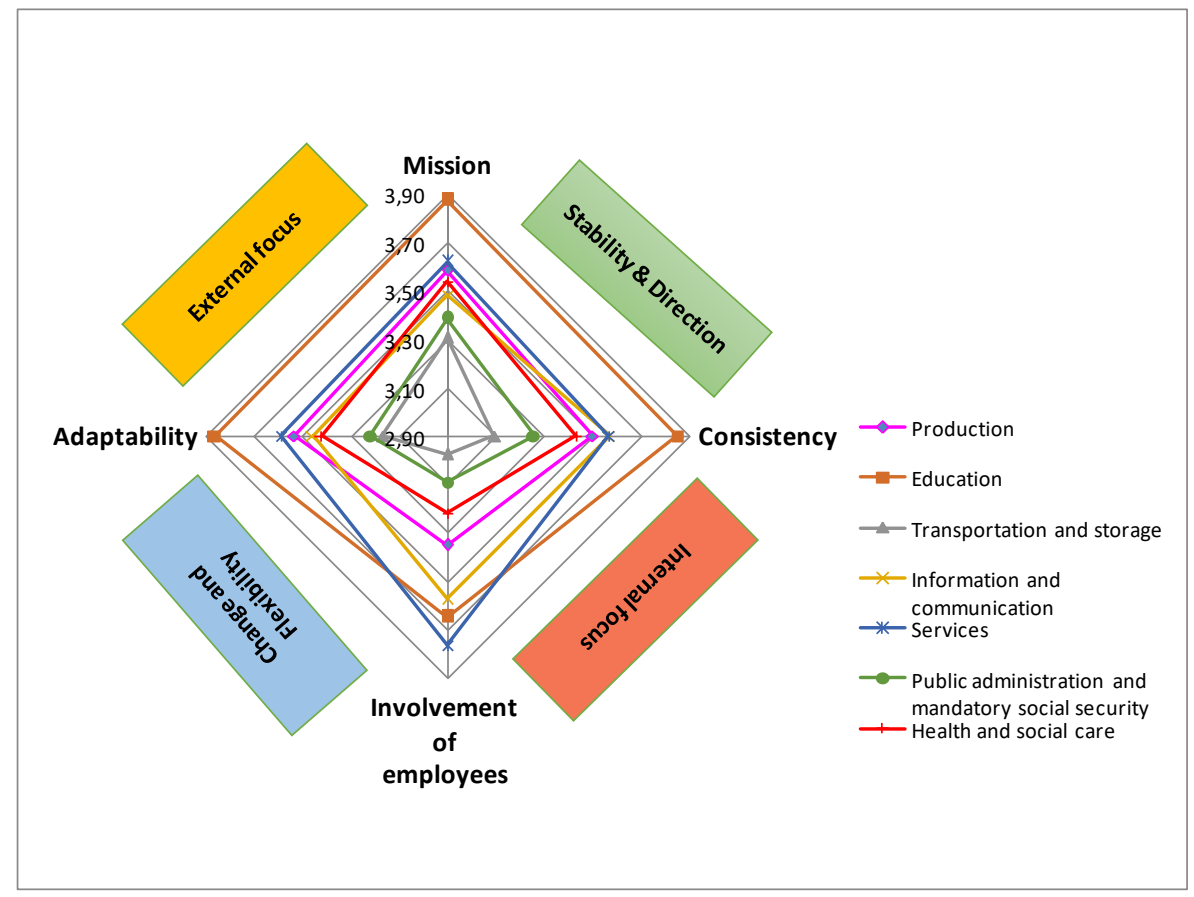

Source: Authors' calculations

3.6. The influence of the organizational culture dimensions on companies in relation to the ownership structure (domestic-foreign organization)

Foreign companies have brought their organizational culture into hitherto fairly stable form of functioning enterprises. Bearing in mind the fact that people from the same country with different organizational cultures work in domestic and foreign companies and that organizational culture implementation period lasted for 15 years, the observed differences are significant in terms of implementation speed changes and can be generalized to countries that are passing, or have recently passed, through a transition, and have some similar cultural characteristics. 
Results of the organizational culture dimensions for the companies in the domestic and foreign ownership have been obtained related to their flexibility, stability, internal integration and external orientation, Table 6 and Figure 8. All obtained values are in range between 3 - neither agree nor disagree, and 4 partly agree.

The lowest values obtained are related to employee involvement. It is shown in those areas where employees can make decisions, have input, and in those areas that are beyond the employee's scope of responsibility.

Table 6. Influence of domestic-foreign ownership on organizational culture

\begin{tabular}{|l|c|c|c|c|c|}
\hline & $\begin{array}{c}\text { Number of } \\
\text { employees }\end{array}$ & Mission & Consistency & $\begin{array}{c}\text { Involvement of } \\
\text { employees }\end{array}$ & Adaptability \\
\hline Foreign & 141 & 3,67 & 3,58 & 3,38 & 3,59 \\
\hline Domestic & 859 & 3,56 & 3,49 & 3,34 & 3,50 \\
\hline
\end{tabular}

Source: Authors' calculations

Figure 8. Differences in dimensions of the Denison model in domestic-owned and in foreign-owned companies.

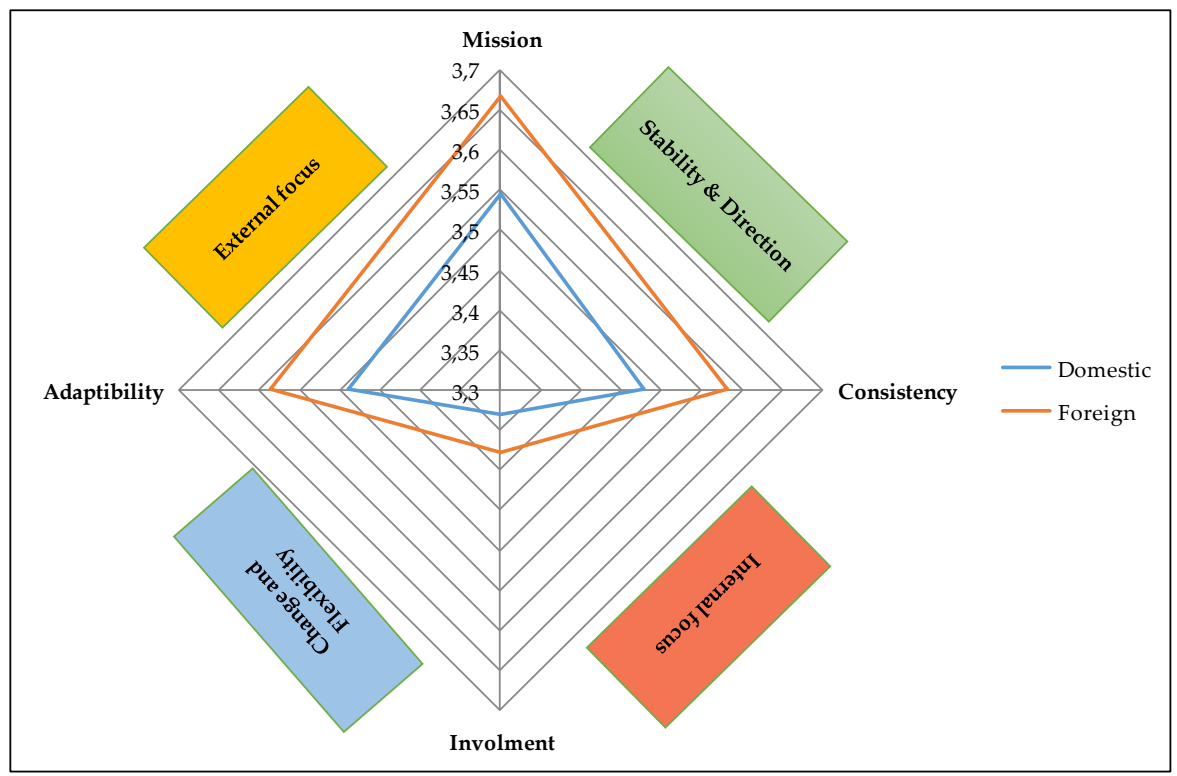

Source: Authors' calculations 
Generally, reviews of research results on the Denison model for the companies in domestic and foreign ownership are shown in Figure VIII. It can be observed that the strength of organizational culture manifestation shares "the same shape" in domestic and foreign companies, which shows similarity in terms of quality, but the difference is noticeable in quantitative terms in favour of foreign companies.

The obtained results show imbalances in the sense that companies have more pronounced external focus and more value for stability than internal integration (related to employee satisfaction) and change \& flexibility (related to Innovation and customer satisfaction), Figure VIII.

The highest values are obtained for the mission dimension. This means that employees are generally aware of their company's purpose for existence. It can be observed that the degree of consensus by all four investigated dimensions is higher in foreign companies operating in Serbia, which can be explained by the influence of different organizational cultures.

The obtained results confirm the fourth derived hypothesis about the influence of domestic or foreign ownership of the company on its organizational culture.

\section{Discussion}

The obtained results show that companies with a small number of employees (up to 9) have a balance between external and internal orientation and stability and flexibility. For those companies the values of the organizational culture, according to the Denison model, are also the highest.

With the increase of the number of employees, the values of the organizational culture were declining, and the lowest value was obtained for employee involvement.

Regarding the observed types of ownership: private, public and government owned, the obtained results show that the best organizational culture, as well as balanced external orientations and internal integration, can be found in privately owned companies.

For state-owned companies and public companies, lesser values of organizational culture dimensions have been obtained. For them, the lowest value was obtained for employee involvement. The current imbalance is such that the result is lower levels of internal integration and adaptability in relation to an external focus and stability of the company.

The results show that activities of companies affect the organizational culture. The highest values for individual dimensions of the organizational culture, 40 
according to the Denison model, were obtained for education, professional, scientific and technical activities. Other activities have lesser values for dimensions of the organizational culture. The lowest values were obtained for transport and storage activities, public administration and mandatory social security, and health and social care.

The highest inclusion of employees was obtained in the activities of services, editions and information and communication. Companies that deal with these activities have a fairly well-balanced external focus and internal integration, as well as stability and ability for adaptability.

In other activities, the inclusion of employees is lower in relation to other dimensions, which makes the imbalance between less internal integration and adaptability in relation to external focus and stability.

Foreign companies have more desirable organizational cultures in terms of achieving higher values for certain dimensions of the organizational culture, although they, as well as companies in domestic ownership, show the lowest values for employee involvement.

According to the authors Marković and Pavlović (2014) improvement of competitiveness of Serbia should be sought in shifting the focus on the microeconomic level of business decision-making and in the acceptance of new economic philosophy, i.e. strategic management and innovation, which is recognized as the critical point of organizational culture of Serbian companies in presented results and the goal that has to be worked on in the future in order to improve the competitiveness of local companies.

The results obtained in this study show that employee involvement in decisionmaking can support the objectives of employers to raise the level of performance and to improve employees' quality of life.

The aim of the research was to highlight the impact of the company's characteristics on its organizational culture. In the case of Serbia, it has been found that the best indicators in terms of a preferred organizational culture are to be found in small firms up to 9 employees, privately owned, in the field of education or professional, scientific and technical activities. They also have the necessary balance of external orientation and internal integration, as well as the balance between stability and flexibility.

The obtained results confirmed the basic research hypotheses: the dimensions of the organizational culture according to the the Denison model are influenced by the company's characteristics. 


\section{Conclusion}

An extremely complex business environment implies the existence of applied managerial knowledge, innovations, and high degree of social skills, as well as organizational culture. To make the company sustainable, organizational culture must match the circumstances in which the company operates. This means that a company must find the balance of the response to external challenges by changing itself while maintaining the necessary stability.

According to Kim S. Cameron and Robert E. Quinn (2006) "most organizational scholars and observers now recognize that organizational culture has a powerful effect on the performance and long-term effectiveness of organizations".

In organizations involved in the presented research, the need for some sort of organizational cultural transformation is obvious. These transformations are in response to a paradigm shift in the broader environment and are necessary to keep a large organization relevant.

\section{References}

Ackoff, L. R.; Magidson, J.; Addison, J. H. (2006). Idealized design; creating an organization's future. Wharton School Publishing, New Jersey.

Ahmady, A. G.; Nikooravesh, A.; Mehrpour, M. Effect of Organizational Culture on Knowledge Management Based on Denison Model, Procedia - Social and Behavioral Sciences, 2016, 230, 387 - 395, doi: 10.1016/j.sbspro.2016.09.049.

Arnold, F. Menadžment-učite od najboljih, Laguna, Belgrade, Serbia, 2015, ISBN: 97886-521-1769-7

Cameron, S. K.; Quinn, E. R. Diagnosing and Changing organizational culture, The Jossey-Bass, A Wiley Imprint, 2006.

Cardona, P.; Rey, C. Management by Missions; Palgrave Macmillan, UK, 2008, ISBN 978-953-246-079-7

Denison, R. D.; Mishra, K. A. Toward a Theory of Organizational Culture and Effectiveness. Organization science, 1995, 6 (2), 204-223, DOI: 10.1287/orsc.6.2.204

Denison, R. D.; Haaland, S.; Goelzer, P. Corporate Culture and Organizational Effectiveness: Is Asia Different From the Rest of the World?, Organizational Dynamics, 2004, 33 (1), 98-109,http://www.denisonconsulting.com/sites/ default/files/documents/resources/denison-2003 asia-different rest-world_0.pdf, (Accessed 9.11.2015)

Denison, R. D.; Neale, S. W. Denison Organizational Culture Survey, Facilitator Guide, 1999. http://www.denisonconsulting.com/Docs/DOCS_A-Z/DOCS_Facilitator _Guide.Pdf. Accessed 20.10.2014. 
Garabinović Dušan, Značaj obrazovanja za razvoj preduzetništva i preduzetnika, Trendovi u poslovanju, vol. 3, br. 2, str. 53-62, 2015

Gavric G., Kirin S., Brzakovic M., 2017., The involvement of employees as a flexibility factor of companies in the Republic of Serbia - empirical research, Industrija, Ekonomski institut, Vol.45, No.2, 65-83

Gavric G., Kirin S., Fedajev A., Talovic V., 2019, The phenomenon of mission in Serbian companies, Fenomen misije u kompanijama u Srbiji, Serbian Journal of management, Vol. 14, No. 1, $145-156$

Gavric, G. \& Stankovic, R. (2015). The presence of factor of stability in organizations culture of organizations in Serbia." 4. International Scientific Conference "Employment, education and entrepreneurship", Faculty of Business Economics and Entrepreneurship, Belgrade, Serbia, 129-146

Gurchiek, K. Culture Keepers; Meet the People behind the New Title in the C-Suit. HR Magazine, 2015, 40-44.

Jovanovic, Z. (2015). "Management and changes in business environment." Ekonomika, $61(2): 143-151$.

Khosla, A. Impact of Organizational Culture on Organizational Performance. The Journal of Institute of Public Enterprise, 2015, 38 (1\&2), 150-164.

Kirin S., Gavrić G., Kirin S. (2019). Organizational culture in Serbian companies according to the Denison model, Economic Analysis, Institute of Economic Sciences, vol. 51, No. 1, 97-108

Kokina, I. (2013). Ostrovska, I. The Analysis of Organizational Culture with the Denison Model (The Case Study of Latvian Municipality). European Scientific Journal 1, 362-368, ISSN: 1857 - 7881 (Print) e - ISSN 1857- 7431

Markovic, J.; Pavlovic, M. Odlike menadžmenta u savremenim kompanijama. Ekonomija teorija I praksa, 2014, 7 (2), 86-113.

Ramon, M; Koller, T. (2016). Exploring adaptability in organizations; Where adaptive advantage comes from and what it is based upon. Journal of Organizational Change Management, 2016, 29 (6), 837-854, DOI 10.1108/JOCM-01-2016-0008

Roozitalab A., Majidi M., Factors affecting on improvement employee empowerment (case study: Saipa corporation), International Review (2017 No.1-2)

Schein, H.E. Organizational Culture. American Psychologist, 1990, 45, 109-119.

Yazdi, A. J.; Eslami, H. Check the Mission and Compatibility as Values of Organizational Culture in Pars Nasuz Co. Based On Denison Model. Interdisciplinary Journal of Contemporary Research in Business, 2015, 6 (9), 33-44.

Yucheng, Z.; Maozhu Jin, C. G., Zhiwei, Z. Research on Evaluation of Enterprise Project Culture Based on Denison Model. Journal of Industrial Engineering and Management JIEM, 2015, 8 (3), 909-927, Online ISSN: 2013-0953 - Print ISSN: 2013-8423 http://dx.doi.org/10.3926/jiem.1400 


\section{Appendix}

According to Denison model for research of organization culture (Denison \& Neale,1999), the following statements have been observed:

Mission:

- "There is a long-term purpose of the company existence as well as its development direction";

- "Our strategy leads other organizations to change the way they compete in the industry";

- "There is a clear mission that gives meaning and direction to our work";

- "There is a clear strategy for the future";

- "Our strategic direction is clear to me";

- "Leaders set goals that are ambitious, but realistic";

- "There is a widespread agreement concerning goals";

- $\quad$ "The leadership has "gone on record" about the objectives we are trying to meet";

- "We continuously track our progress towards our stated goals";

- "People understand what needs to be done for us to succeed in the long run";

- "We have a common vision of what the organization will be like in the future";

- "Short-term thinking seldom compromises our long-term vision";

- "Leaders have a long-term way of thinking";

- "Our vision creates excitement and motivation for our employees";

- "We are able to meet short-term demands without compromising our long-term vision."

Consistency:

- "The leaders and managers do what they say";

- "There is a characteristic management style and a distinct set of management practices";

- "There is a clear and consistent set of values that governs the way we do business";

- "Ignoring core values will get you in trouble";

- "There is an ethical code that guides our behaviour and tells us right from wrong";

- "When disagreements occur, we work hard to achieve "win-win" solutions";

- "There is a "strong" culture";

- "It is easy to reach consensus, even on difficult issues and key issues";

- "There is a clear agreement about the right way and the wrong way to do things";

- "Our approach to doing business is very consistent and predictable";

- "People from different parts of the organization share a common perspective";

- "It is easy to coordinate projects across different parts of the organization";

- "Working with someone from another part of this organization is not like working with someone from a different organization"; 
- "There is good alignment of goals across all levels".

Involvement of employees:

- "Most employees are highly involved in their work";

- "Decisions are usually made at the level where the best information is available";

- "Information is widely shared so that everyone can get the information he or she needs when it's needed";

- "Everyone believes that he or she can have a positive impact";

- "Business planning is ongoing and involves everyone in the process to some degree";

- "Cooperation across different parts of the organization is actively encouraged";

- "People work like they are part of a team";

- "Teamwork rather than hierarchy is encouraged to get things done";

- "Teams are our primary building blocks";

- "Work is organized so that each person can see the relationship between his or her job and the goals of the organization";

- "Authority is delegated, so that people can act on their own";

- "There is a continuous investment in developing the skills of employees";

- "The capabilities of people are viewed as an important source of competitive advantage";

- "Problems seldom arise because we have the skills necessary to do the job".

Adaptability:

- "The way things are done is very flexible and easy to change";

- "We respond well to competitors and other changes in the business environment";

- "New and improved ways to do work are continually being adopted";

- "Attempts to create change are seldom met with resistance";

- "Different parts of the organization often cooperate to create change";

- 'Customers' wants and needs are looked at and have a direct influence on decisions and business";

- "We encourage direct contact with customers by our people";

- "We view failure as an opportunity for learning and improvement";

- "Innovation and risk taking are encouraged and rewarded";

- "Learning is an important objective in our day-to-day work";

- "We are familiar with the work of other sectors at all times". 